\title{
Uusia menetelmiä viljelijöiden päätoimisuusasteen määrittelyyn
}

\author{
Risto A. Seppälä ${ }^{1)}$ ja Maija Puurunen ${ }^{2)}$, \\ ${ }^{1)}$ MTT Taloustutkimus Luutnantintie 1300410 Helsinki, risto.a.seppala@mtt.fi \\ ${ }^{2)}$ Etelä-Savon TE-keskus PL 16450100 Mikkeli, maija.puurunen@te-keskus.fi
}

Viljelijäväestön tulotasoa ja sen muutoksia tutkittaessa joudutaan usein tarkastelemaan myös harjoitetun maatalouden merkitystä viljelijän kokonaistulonmuodostuksessa. Suomalaisissa tarkasteluissa maatilat on useimmiten jaettu neljään ryhmään sen perusteella, mikä osuus viljelijäpuolisoiden tuloista tulee maataloudesta. Suora, tulo-osuuteen perustuva, ryhmittely kuitenkin huomioi herkästi väliaikaisten tulonvaihteluiden (esim. katovuosi, eläintaudit) vaikutuksen luokittelussa. Luokittelun satunnainen vaeltelu aiheuttaa ylimääräistä virhettä aikasarjatarkasteluihin. Vakaamman luokittelijan muodostamiseksi on tulotasotutkimuksen yhteydessä tutkittu mahdollisuutta hyödyntää tulotietojen lisäksi myös työpanoksen käyttötietoja maatalouden päätoimisuusasteen määrittelyssä.

Luokitus muodostettiin vuoden 2003 verolomakkeilta saatavien viljelijöiden tulotietojen ja samana vuonna MMM/TIKE:n keräämien Maatalouden rakennetutkimuksen työvoimankäyttötietojen perusteella. Tulo- ja työnkäyttötietojen pohjalta tilat jaettiin ryhmittelyanalyysillä samankaltaisten tilojen ryhmiin. Vastaavan tyyppistä analyysiä on sovellettu tekijöiden aiemmassa tutkimuksessa vuoden 2000 tietoihin. Aiempaan tutkimukseen verrattuna tässä tutkimuksessa käytettiin yksinkertaisempaa analyysimenettelyä ja suppeampaa aineistoa. Aiemmassa tutkimuksessa vuoden 2000 tiedot oli käytettävissä n. 8000 tilalta kun taas tässä vastaavat tiedot oli saatavissa vain n. 4200 tilalta lähtöaineistojen erilaisen keruutavan vuoksi.

Analyysimenetelmien osalta merkittävimmät muutokset olivat tarkastelussa käytettävien muuttujien määrän huomattava vähentäminen (2000 75kpl - 20033 kpl) sekä aineiston analysoiminen suoraan klusterianalyysillä. Analyysissä käytettiin muuttujina maataloustulojen osuutta kokonaistuloista ja viljelijäpuolisoiden työajankäyttöä TIKE:n kyselyn 7-portaisen luokituksen mukaan. Vuoden 2000 tietojen analyysissä oli käytetty suurempaa joukkoa yksityiskohtaisempia tietoja maataloudesta, tulosta, menoista ja omaisuudesta. Tätä muuttujajoukkoa oli "tiivistetty” faktorianalyysillä ennen klusterianalyysiä.

Klusteroinnin perusteella aineisto jaettiin kuuteen ryhmään, jotka edustavat erityyppisiä maatiloja. Tulosten mukaan viljelijäpuolisoiden tiloista $35 \%$ voidaan katsoa olevan sekä tulo että työajankäytön suhteen päätoimisia kotieläintiloja. Näillä tiloilla maatalouden osuus kokonaistuloista on n. 86 \% ja molempien puolisoiden työaika käytetään miltei kokonaan maataloudessa. Tiloista 19 \%:lla hankitaan keskimäärin 55 \% kokonaistuloista palkkatyöstä ja työajan perusteella molemmat viljelijäpuolisoista ovat ainakin sivutoimisesti tilan ulkopuolella töissä. Loput 46 \% tiloista jakautui neljään suunnilleen samankokoiseen ryhmään, joiden voidaan katsoa sijoittuvan maatalouden päätoimisuuden asteen perusteella em. ääriryhmien väliin. Täten voidaan todeta aiempaan verrattuna huomattavasti selkeämmällä analysointitavalla saavutettavan asetettujen luokitustavoitteiden mukaisia tuloksia.

Asiasanat: tilastoanalyysi, tulot, tulotyypit 


\section{Johdanto}

Viljelijäväestön harjoittaman maatalouden merkitys toisaalta kokonaistulojen rakenteen ja toisaalta pääomien ja työajan käytön suhteen vaihtelee maatilojen kesken. Maatalouselinkeinon harjoittaminen jaetaankin usein tapahtuvaksi päätoimisilla ja ei-päätoimisilla maatiloilla. Vaikka jaottelua päätoimisiin ja ei-päätoimisiin viljelijöihin/tiloihin käytetään eri yhteyksissä, ei yhtä yleispätevää luokitteluperustetta ilmiön kuvaamiselle ole olemassa (Peltola 1999).

Suomalaisissa tulotasotarkasteluissa maatilat on useimmiten jaettu neljään ryhmään sen perusteella, mikä osuus viljelijäpuolisoiden tuloista tulee maataloudesta. Viljelijäväestön tulotasoa ja sen muutoksia on tutkittu MTT Taloustutkimuksessa jo usean vuosikymmenen ajan (Puurunen 1987, Puurunen 1990, Väre 2000). Suora, tulo-osuuteen perustuva, luokittelu olettaa kuitenkin tulojen pysyvän vakaana eri vuosina. Todellisuudessa kuitenkin maatalouden tulot vaihtelevat mm. kasvukauden sääolojen perusteella. Tämänkaltaiset maatalouden tuloissa tapahtuvat väliaikaiset vaihtelut heijastuvat herkästi luokittelutuloksessa, joten sama maatila voi peräkkäisinä vuosina sijoittua eri päätoimisuusluokkiin vaikka todellisia muutoksia eri tulolähteiden osuuksissa ei olisikaan tapahtunut. Näin muodostunut luokittelun sattumanvarainen ja tarkasteltavan ilmiön kannalta aiheeton vaeltelu aiheuttaa ylimääräistä virhettä aikasarjatarkasteluihin. Vakaamman luokittelijan muodostamiseksi on tulotasotutkimuksen yhteydessä tutkittu mahdollisuutta hyödyntää tulotietojen lisäksi myös työpanoksen käyttötietoja maatalouden päätoimisuusasteen määrittelyssä.

\section{Aineisto ja menetelmät}

Uuden luokitustavan muodostamiseksi tarvittavat tulo- ja työpanoksenkäyttötiedot jouduttiin yhdistelemään eri lähdeaineistoista. Aineistolähdettä josta olisi valmiiksi saanut sekä viljelijäpuolisoiden kokonaistulotiedot riittävällä tarkkuudella että työpanoksen käyttötiedot ei ole olemassa Suomessa. Tulo- ja työnkäyttötietojen pohjalta tilat jaettiin ryhmittelyanalyysillä samankaltaisten tilojen ryhmiin. Vastaavan tyyppistä analyysiä on sovellettu tekijöiden aiemmassa tutkimuksessa vuoden 2000 tietoihin (Puurunen ja Seppälä 2004).

Maatilojen tulojen osalta aineisto koostuu Tilastokeskuksen Maatilatalouden yritys- ja tulotilaston (MYTT) ja Maatilatalouden tulo- ja verotilaston tietoihin maa- ja metsätalouden veroilmoituksista luonnollisten henkilöiden viljelemiltä tiloilta (Tilastokeskus 2006). Työpanoksen käyttötiedot saatiin tutkimuksen käyttöön MMM/TIKE:n suorittaman maatalouden rakennetutkimuksen tiedoista (TIKE 2007) kyselyn 7-portaisen luokituksen mukaisesti. Sekä tulo- että työpanostiedot oli kerätty vuonna 2003. Aiempaan tutkimukseen verrattuna tässä jouduttiin käyttämään huomattavasti suppeampaa aineistoa. Aiemmassa tutkimuksessa vastaavat tiedot vuodelta 2000 olivat käytettävissä n. 8000 tilalta. Tässä tutkimuksessa tiedot oli saatavissa vain n. 4200 tilalta lähtöaineistojen erilaisen keruutavan vuoksi. Vuoden 2000 tiedoista aineistoa koostettaessa tulotietojen lähde oli sama kuin tässä tutkimuksessa, mutta työvoimankäyttötiedot olivat peräisin MMM/TIKE:n tekemästä maatalouslaskennasta, joka kattoi käytännössä kaikki maatilat. Täten työpanoksen käyttötiedot oli mahdollista yhdistää kaikille tiloille joilta oli käytettävissä tulotiedot. Vuonna 2003 MMM/TIKE keräsi työvoimankäyttötiedot rakennetutkimuksen otantakyselyn yhteydessä vain noin 35000 maatilalta. Joten vuoden 2003 aineistoa muodostettaessa jouduttiin yhdistämään kahden toisistaan riippumattomasti tehdyn otannan (verolomaketietojen ja rakennetutkimuksen) tiedot sikäli kun aineistoista löytyi yhteisiä tiloja.

Analyysimenetelmien osalta merkittävä muutos oli sen yksinkertaistaminen. Analysointia yksinkertaistettiin sekä menetelmien että käytettävän aineiston osalta. Vuoden 2000 tietojen analyysissä hyödynnettiin suurta joukkoa yksityiskohtaisia tietoja maataloudesta, tuloista, menoista ja omaisuudesta, ja käytettyjä muuttujia oli kaikkiaan 75 kappaletta. Tämän suuren muuttujajoukon perusteella tilat ryhmiteltiin kaksivaiheisesti. Ensimmäisessä vaiheessa muuttujajoukkoa "tiivistettiin” faktorianalyysillä. Tiivistämisen jälkeen päästiin toisessa vaiheessa varsinaiseen tilojen ryhmittelyyn klusterianalyysillä.

Tässä tutkimuksessa vuoden 2003 aineistosta muodostettiin kolme muuttujaa joiden perusteella tilat ryhmiteltiin suoraan klusterianalyysillä. Analyysissä käytettiin muuttujina maataloustulojen osuutta kokonaistuloista ja viljelijän sekä hänen puolisonsa maataloudessa käyttämän työajan määriä. Työajankäyttö oli määritetty MMM/TIKE:n rakennetutkimuksen kyselyn 7-portaisen luokituksen mukaan.

Ryhmittelyssä käytetty klusteri- tai ryhmittelyanalyysi muodostaa samankaltaisten havaintojen ryhmiä havainnoista mitattujen ominaisuuksien perusteella. Klusterianalyysiä varten on olemassa laaja 
joukko erilaisia menetelmiä ja niiden variaatioita. Tässä käytettiin ns. K-means -algoritmia, joka yhdistää havainnot oletettuihin ryhmäkeskipisteisiin keskipisteen ja havainnon euklidisen etäisyyden perusteella. Kukin havainto/tila liitetään sitä lähinnä olevan keskipisteen edustamaan ryhmään (Mustonen 1995, Ranta ym. 1994).

\section{Tulokset}

Tavoitteena oli jakaa tilajoukko ryhmiin siten, että muodostuu ensinnäkin tilaryhmä, jossa sekä tuloettä työpanostiedot viittaavat viljelijäpuolisoiden päätoimisesti harjoittamaan maatalouteen, sekä lisäksi eri tavoin osa-aikaisten tilojen ryhmiä.

Klusteroinnin perusteella aineisto jaettiin kuuteen ryhmään. Ryhmittelytuloksen arvioinnissa käytettiin apuna CCC ja Pseudo-F tunnuslukuja sekä muodostetun ryhmittelyn kykyä selittää aineiston vaihtelua (luokittelijan selitysaste) (Puurunen \& Seppälä 2004). Tulokset esitetään taulukossa 1. Tässä esitettävä ryhmittelytulos selitti $82 \%$ aineiston vaihtelusta. Ryhmämäärän nostaminen yhdellä olisi nostanut selitysastetta vain noin 1,5 prosenttiyksikköä ja vastaava lasku pienentänyt selitysastetta 3 prosenttiyksikköä.

Taulukko 1. Ryhmittelyanalyysin muodostamien tilaryhmien ominaisuudet.

\begin{tabular}{|c|c|c|c|c|c|c|}
\hline & 1 & 2 & 3 & 4 & 5 & 6 \\
\hline ryhmän osuus kokojoukosta & $9.4 \%$ & $10.7 \%$ & $15.5 \%$ & $10.4 \%$ & $19.2 \%$ & $34.9 \%$ \\
\hline \multicolumn{7}{|c|}{ Tulolähteen osuus kokonaistuloista } \\
\hline Maatalous & $56 \%$ & $18 \%$ & $61 \%$ & $38 \%$ & $9 \%$ & $86 \%$ \\
\hline Metsätalous & $6 \%$ & $11 \%$ & $4 \%$ & $16 \%$ & $5 \%$ & $4 \%$ \\
\hline Palkkatulot & $20 \%$ & $41 \%$ & $21 \%$ & $17 \%$ & $55 \%$ & $2 \%$ \\
\hline Viljelijän palkkatulot & $8 \%$ & $9 \%$ & $1 \%$ & $8 \%$ & $24 \%$ & $1 \%$ \\
\hline Puolison palkkatulot & $12 \%$ & $32 \%$ & $20 \%$ & $9 \%$ & $30 \%$ & $1 \%$ \\
\hline Muu elinkeinotoiminta & $4 \%$ & $9 \%$ & $2 \%$ & $6 \%$ & $7 \%$ & $1 \%$ \\
\hline Omaisuustulot & $5 \%$ & $12 \%$ & $4 \%$ & $13 \%$ & $14 \%$ & $3 \%$ \\
\hline Tulonsiirrot & $9 \%$ & $9 \%$ & $8 \%$ & $10 \%$ & $11 \%$ & $4 \%$ \\
\hline \multicolumn{7}{|l|}{ Alat ja eläinmäärät } \\
\hline Eläimiä yht. ny. & 13 & 19 & 45 & 35 & 2 & 53 \\
\hline Pelto ha. & 44 & 38 & 53 & 40 & 24 & 49 \\
\hline Metsä ha. & 53 & 55 & 54 & 64 & 44 & 56 \\
\hline \multicolumn{7}{|c|}{ Työajankäyttö maataloudessa (0-6) } \\
\hline Viljelijä & 2.72 & 5.01 & 5.52 & 5.43 & 1.78 & 5.72 \\
\hline Puoliso & 2.31 & 1.00 & 1.17 & 4.97 & 0.90 & 5.33 \\
\hline \multicolumn{7}{|c|}{ Työssäkäynti tilan ulkopuolella (0-2) } \\
\hline Viljelijä & 0.68 & 0.48 & 0.15 & 0.36 & 1.22 & 0.13 \\
\hline Puoliso & 0.71 & 1.58 & 1.20 & 0.35 & 1.42 & 0.07 \\
\hline
\end{tabular}

Taulukossa 1. esitetään ryhmien 1-6 keskimääräiset tiedot eri tulolähteiden osuuksista kokonaistuloista, kokonaiseläinmäärästä, pelto- ja metsäalasta ja työajankäytöstä luokka-asteikon mukaan mitattuna. Maatalouden työajan käyttö on mitattu 7-portaisella asteikolla. Käytetty luokkajako oli vuotuisena työaikana esitettynä 0h, 1-499 h, 450-899 h, 900-1349 h, 1350-1799 h, 1800-2999 h ja yli 3000 työtuntia vuodessa. Luokituksessa 0 luokka vastaa 0 tuntia työaikaa ja 6 luokka yli 3000 tuntia vuodessa. Työssä käynti tilan ulkopuolella mitattiin kolmiportaisella asteikolla 0 (ei töissä tilan ulkopuolella), 1 (sivutoimisesti töissä tilan ulkopuolella) ja 2 (päätoimisesti töissä tilan ulkopuolella).

Tulosten mukaan viljelijäpariskuntien tiloista noin $35 \%$ voidaan katsoa olevan sekä tulo- että työajankäytön suhteen päätoimisia kotieläintiloja (ryhmä 6). Näillä tiloilla maatalouden osuus kokonaistuloista on n. 86 \% ja molempien puolisoiden työaika käytetään miltei kokonaan maataloudessa. Vastaavasti tässä tilaryhmässä työssäkäynti tilan ulkopuolella on hyvin harvinaista. Tiloista $19 \%$ hankkii keskimäärin 55 \% kokonaistuloistaan palkkatyöstä (ryhmä 5). Tässä ryhmässä keskimäärin myös 
työaikatietojen mukaan viljelijäpuolisoista molemmat käyvät vähintäänkin sivutoimisesti töissä tilan ulkopuolella. Tulosten mukaan näiden kahden ryhmän voidaan katsoa edustavan tarkasteltavassa tilajoukossa päätoimisuus asteikon ääripäitä. Päätoimisimpana pidettävässä ryhmässä 6 keskimääräinen tilakoko on sekä eläinten määrällä että pinta-alalla mitattuna selvästi tilaryhmää 5 suurempi. Etenkin eläinmäärällä mitattuna ryhmien 6 ja 5 välinen ero on huomattavan suuri, yli 20-kertainen.

Loput 46 \% tiloista jakautui neljään suunnilleen samankokoiseen ryhmään, kooltaan noin 10 \% koko tilajoukosta. Poikkeuksena ryhmä 3, joka on kooltaan hiukan suurempi; $15.5 \%$ tilajoukosta. Näiden neljän tilaryhmän voidaan katsoa sijoittuvan maatalouden päätoimisuuden asteen perusteella em. ääriryhmien 6 ja 5 väliin.

Ryhmässä 3 maatalouden osuus kokonaistuloista on ryhmistä toiseksi suurin, $61 \%$, mutta myös palkkatulot, etenkin puolisolla muodostavat $20 \%$ osuudellaan merkittävän tulonlähteen. Ryhmässä keskimääräinen peltoala on kaikkein suurin ja eläinmäärä toiseksi suurin. Työajan käytön perusteella viljelijä tekee maataloudessa töitä keskimäärin yli 1800 tuntia vuodessa ja puoliso on vähintäänkin sivutoimisesti töissä tilanulkopuolella. Tilaryhmän voi sanoa edustavan peltoalaltaan suurta kotieläintilaa, jolla eläimet eivät kuitenkaan merkittävästi rajoita puolison työssäkäyntiä tilan ulkopuolella.

Kolmanneksi suurin maatalouden osuus kokonaistuloista on tilaryhmässä 1, 56 \%. Tässä ryhmässä palkkatulojen osuus on $20 \%$, vain prosenttiyksikön verran pienempi kuin ryhmässä 3 . Tässä ryhmässä molemmat viljelijäpuolisot työskentelevät maataloudessa työaikaluokkien 2-3 verran. Eläimiä tässä ryhmässä on toiseksi vähiten ryhmän 5 jälkeen. Ryhmän tietojen perusteella kyseessä olisi tilajoukko jossa keskimäärin peltoa on huomattavasti suhteessa eläinmäärään, molemmat viljelijäpuolisot osallistuvat tilan töihin mutta hankkivat samalla jonkin verran tuloja myös tilan ulkopuolelta.

Tilaryhmässä 4 metsätulojen osuus kokonaistuloista on muita ryhmiä selvästi suurempi $16 \%$, mutta maatalouden osuus keskitasoa (38 \%) muihin verrattuna. Kotieläimiä tilaryhmässä on kolmanneksi eniten ja metsää selvästi muita ryhmiä enemmän. Työajankäyttö viittaisi molempien viljelijäpuolisoiden osalta päätoimiseen maatalouteen. Kyseistä tilaryhmää voitaisiinkin luonnehtia kotieläinvaltaisiksi maatiloiksi joilla kuitenkin metsätuloilla on huomattava merkitys tulonmuodostuksessa.

Viimeiseksi tulosten tarkastelussa jätetyssä tilaryhmässä 2 on maatalouden tulo-osuus toiseksi pienin kuten myös tilakoko, sekä eläinmäärällä että peltoalalla mitattuna, kaikista ryhmistä. Palkkatulojen osuus sitä vastoin on toiseksi suurin. Työajan käyttötietojen perusteella viljelijä työskentelee tilalla päätoimisesti ja puoliso selvästi enemmän kuin osa-aikaisesti tilan ulkopuolella. Laskettujen tulosten perusteella tilaryhmää 2 voisi kuvailla keskimääräistä pienemmiksi tiloiksi jotka viljelijä hoitaa pääasiassa yksin ja puolison palkkatuloilla on merkittävä vaikutus viljelijäpuolisoiden kokonaistuloihin.

\section{Johtopäätökset}

Esitettyjen tulosten perusteella ryhmittelyanalyysiä voidaan menestyksekkäästi käyttää maatilojen ryhmittelyyn. Muodostetulle ryhmittelylle pystytään antamaan selkeä tulkinta taustatietojen perusteella. Aiempaan tutkimukseen verrattuna analysoinnissa tehdyt yksinkertaistukset toisaalta vähensivät tulokseksi saatavien tilaryhmien määrää, mutta toisaalta saadut tulokset olivat selkeämmin tulkittavissa maatalouden päätoimisuuden/osa-aikaisuuden suhteen. Täten voidaan todeta aiempaan verrattuna huomattavasti selkeämmällä analysointitavalla saavutettavan asetettujen luokitustavoitteiden mukaisia tuloksia.

Varsinaisten luokittelukriteerien muodostamista varten analyysiä olisi kuitenkin laajennettava kattamaan useampia tarkasteluvuosia, jotta mahdollisen satunnaisvaihtelun merkitys tuloksissa pienenisi. Lisäksi jakauman ääripäiden väliin jäävien ryhmien määrää, kokoa ja merkitystä ilmiön selittämisen kannalta olisi tarkasteltava perusteellisemmin. 


\section{Kirjallisuus}

Mustonen, S. 1995. Tilastolliset monimuuttujamenetelmät. Helsingin yliopisto. Tilastotieteen laitos. Survo Sys-tems Oy. Helsinki. 205 s. verkkojulkaisu: http://www.survo.fi/monim/index.html .

Peltola, A. 1999. Päätoimisuuskriteerit suomalaisilla maatiloilla. Maatalouden taloudellisen tutkimuslaitoksen Selvityksiä 14/99. 70 s.

Puurunen, M. 1987. Viljelijäväestön tulojen vertaaminen muiden väestöryhmien tuloihin. Maatalouden taloudellisen tutkimuslaitoksen tiedonantoja $134.171 \mathrm{~s}$.

Puurunen, M. 1990. A Comparative Study on Farmers' Income. Maatalouden taloudellisen tutkimuslaitoksen julkaisuja 62. $114 \mathrm{~s}$.

Puurunen, M., Seppälä, R.A. 2004. Osa-aika- ja päätoimitilojen tulot ja työnkäyttö. In: Toim. Anneli Hopponen ja Marketta Rinne. Maataloustieteen Päivät 2004, 12.-13.1.2004 Viikki, Helsinki [: esitelmät ja posterit]. Suomen maataloustieteellisen seuran tiedote 19: $4 \mathrm{p}$.

http://www.smts.fi/MTP\%20julkaisu\%202004/esi04/ma32.pdf Julkaistu 5.1.2004

Ranta, E., Rita, H. \& Kouki, J. 1994. Biometria. Tilastotiedettä ekologeille. Viides painos. Helsinki. $569 \mathrm{~s}$.

TIKE. 2007. Rakennetutkimusrekisterin WWW-sivut.

http://www.mmmtike.fi/fi/index/tilastojatietopalvelut/tietopalvelu/rekistereiden tietosisalto/rakennetut kimusrekisteri.html . viitattu 5.12.2007.

Tilastokeskus. 2006. Maatilatalouden yritys- ja tulotilasto 2003. Suomen virallinen tilasto. Maa-, metsä-, ja kalatalous 2006. 67 s.

Väre, M. 2000. Viljelijöiden tulotasovertailu. Maatalouden taloudellisen tutkimuslaitoksen tutkimuksia 242. $168 \mathrm{~s}$. 